\title{
Nanostructured titanium dioxide for use in bone implants: a short review
}

\section{(Dióxido de titânio nanoestruturado para uso em implantes ósseos: uma breve revisão)}

\author{
I. A. Bezerra Neta ${ }^{1 *}$, M. F. Mota ${ }^{1}$, H. L. Lira ${ }^{1}$, G. A. Neves ${ }^{1}$, R. R. Menezes ${ }^{1}$ \\ ${ }^{I}$ Federal University of Campina Grande, Academic Unit of Materials Engineering, Materials Technology \\ Laboratory, Av. Aprígio Veloso 882, 58109-970, Campina Grande, PB, Brazil
}

\begin{abstract}
Titanium dioxide $\left(\mathrm{TiO}_{2}\right)$ based nanostructured materials have shown great potential for use in implants thanks to their excellent physicochemical properties, such as high specific surface area, ability to elicit positive cell response, and stability in body fluids. However, there are few studies in the literature that focus on the use of nanostructured $\mathrm{TiO}_{2}$ to support cell growth and bone regeneration. The purpose of this survey is to review the state of the art of $\mathrm{TiO}_{2}$ for use in bone implants, as well as provide insight into its characteristics and synthesis methods. Studies of the biological properties of nanostructured $\mathrm{TiO}_{2}$ are described, establishing its potential for the biomedical field.
\end{abstract}

Keywords: nanostructured materials, titanium dioxide, biomaterials.

Resumo

Os materiais nanoestruturados à base de dióxido de titânio (TiO $)$ têm demonstrado grande potencial para uso em implantes graças às suas excelentes propriedades físico-químicas, como alta área superficial especifica, capacidade de provocar resposta celular positiva e estabilidade nos fluidos corporais. No entanto, existem poucos estudos na literatura que se concentram no uso de TiO nanoestruturado para fins de suporte ao crescimento celular e regeneração óssea. O objetivo desta pesquisa é revisar o estado da arte do $\mathrm{TiO}_{2}$ para uso em implantes ósseos, além de fornecer informações sobre suas características e métodos de síntese. São descritos estudos das propriedades biológicas do $\mathrm{TiO}_{2}$ nanoestruturado, estabelecendo seu potencial para o campo biomédico.

Palavras-chave: materiais nanoestruturados, dióxido de titânio, biomateriais.

\section{INTRODUCTION}

Materials for bone repair or regeneration are needed in many situations in orthopedics and orthodontics and are critical for people suffering from osteoporosis, bone cancer, joint and spinal disease, and disorders. As the world population ages and cases of osteoporosis and bone trauma increase sharply among the elderly, the number of individuals that need bone implants to boost bone regeneration has grown dramatically in recent decades [1, 2]. The use of autogenous and allogeneic bone grafts may help in the treatment of bone lesions. However, they have numerous disadvantages, such as the need for secondary surgery, limitation in the number of grafts, risk of infections, and immune responses, which may cause other severe health problems [3, 4]. In recent years, most orthopedic research has focused on nanostructured biomaterials due to their similarities to the natural physiological environment [511]. Nanoscale morphology has unique properties such as high surface area and a higher degree of biological plasticity than other microstructures [12-14]. Studies have shown that the surface or chemical properties of these microstructures are similar to those of native bone, affecting how cells adhere to their surface, their biochemical functions, and cell differentiation [15-17].

Several materials have been studied for the fabrication of nanostructures for biomedical applications in bone repair [18-24], including $\mathrm{TiO}_{2}$. The mechanical properties, biocompatibility, low cytotoxicity, stability in body fluids [25-30], and corrosion resistance of $\mathrm{TiO}_{2}$ give it a great potential for use in bone implants [31,32]. Researches [15, 33-35] have shown that nanostructured $\mathrm{TiO}_{2}$ elicits a favorable molecular response and osseointegration, with better bone formation than non-nanostructured materials. However, despite advances in the development of nanostructured $\mathrm{TiO}_{2}$ systems for bone repair, review articles addressing this topic are still scanty. Therefore, this paper aims to review the characteristics and fabrication methods of nanostructured titanium dioxide and to focus on studies that evaluated its potential for bone implants.

\section{CHARACTERISTICS OF TITANIUM DIOXIDE}

*ioneamorimbezerra@gmail.com

Dhttps://orcid.org/0000-0002-5744-8055
Titanium dioxide is a white solid that is technologically 
important due to its numerous properties [36,37], such as low modulus of elasticity, good tensile strength, biocompatibility, and corrosion resistance, as well as its abundance [38-41]. $\mathrm{TiO}_{2}$ has been used in a variety of applications, e.g., in biomedicine as catalyst support [37, 42], in water and air purification systems $[17,43]$, in pigments or opacifiers, in cosmetics [36, 37] and solar cells [44, 45], and in various biomedical applications [46, 47].

Under atmospheric pressure, $\mathrm{TiO}_{2}$ exists in 3 polymorphic forms (Table I), known as rutile, anatase, and brookite $[38,39]$. These polymorphs can be described by a $\mathrm{Ti}^{4+}$ cation coordinated by 6 oxygen atoms, forming a distorted octahedron [45, 48, 49], whose polymorphic shapes are dictated by the way these octahedrons combine. The anatase form has a tetragonal structure and a unit cell with 4 titanium dioxide molecules (Fig. 1a). The rutile form also has a

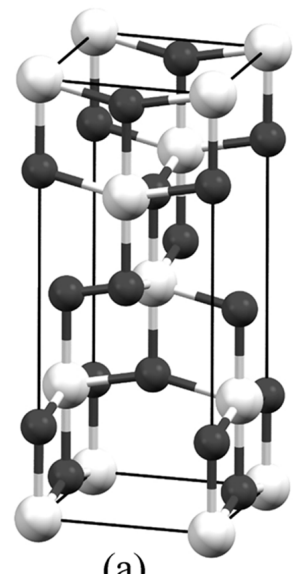

(a)

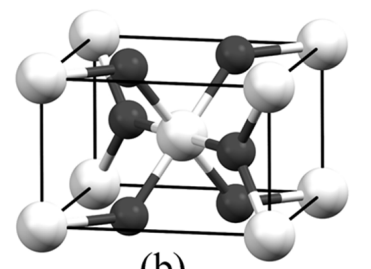

(b)

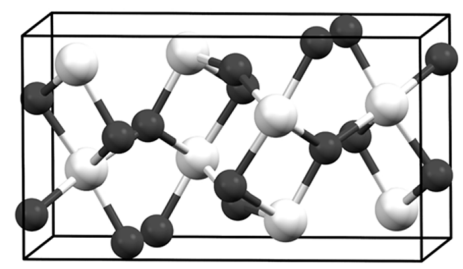

(c)
Figure 1: Crystalline structure of: a) anatase; b) rutile; and c) brookite. Gray and white spheres represent $\mathrm{O}$ and $\mathrm{Ti}$ atoms, respectively.

[Figura 1: Estrutura cristalina de: a) anatásio; b) rutilo; e c) brookita. Esferas cinza e branca representam átomos de $\mathrm{O}$ e Ti, respectivamente.] tetragonal structure and two titanium dioxide molecules per unit cell (Fig. 1b). Brookite has an orthorhombic structure and a unit cell containing 8 molecules (Fig. 1c). Compared to anatase and rutile, brookite is the least dense form of $\mathrm{TiO}_{2}$ $[42,44,50,51]$. The properties of $\mathrm{TiO}_{2}$ vary according to the polymorphic phase (Table I). Rutile is the most stable phase, while anatase and brookite are metastable and can be irreversibly transformed into rutile at high temperatures. This phase transition and stability can be influenced by impurities, defects, grain size, reaction atmosphere, and synthesis conditions [49]. In addition, the stability of polymorphic phases depends on grain size. It has been reported that anatase is stable in crystallite sizes smaller than $11-45 \mathrm{~nm}$ due to the high surface free energy associated with this particle size $[50,52]$.

$\mathrm{TiO}_{2}$ is an n-type semiconductor whose electronic and optical properties are influenced by the nature of the conduction band [71, 72]. The photocatalytic process is based on the absorption of UV light by titanium dioxide. When the level of photon energy is greater than or equal to that of the band gap, the photoexcited electrons jump from the valence band to the conduction band, leaving electron holes (Eq. A). In aqueous media, reactions may occur between excited $\mathrm{TiO}_{2}$ and the medium. Electron holes interact with water or with the hydroxyl radical, forming hydrogen and hydroxyl ions (Eqs. B and C). Oxygen can also be adsorbed on titanium dioxide particles, reacting with electrons in the conduction band and generating superoxide (Eq. D) [37, 73-75]:

$$
\begin{aligned}
& \mathrm{TiO}_{2}+\mathrm{hv}(\mathrm{UV}) \leftrightarrow \mathrm{h}^{+}+\mathrm{e}^{-} \\
& \mathrm{h}^{+}+\mathrm{H}_{2} \mathrm{O} \leftrightarrow \mathrm{H}^{+}+\mathrm{OH} \\
& \mathrm{h}^{+}+\mathrm{OH}^{-} \leftrightarrow \cdot \mathrm{OH} \\
& \mathrm{e}^{-}+\mathrm{O}_{2} \leftrightarrow \mathrm{O}_{2}^{-}
\end{aligned}
$$

\begin{tabular}{|c|c|c|c|c|}
\hline Property & Anatase & Rutile & Brookite & Ref. \\
\hline Structure & Tetragonal & Tetragonal & Orthorhombic & {$[45,53-56]$} \\
\hline Space group & $\mathrm{I} 4_{1} / \mathrm{amd}$ & $\mathrm{P} 42 / \mathrm{mnm}$ & Pbca & {$[43,44,57-59]$} \\
\hline Unit cell parameters $(\mathrm{nm})$ & $\begin{array}{c}a=0.3733-0.3785 \\
c=0.937-0.9515\end{array}$ & $\begin{array}{l}a=0.45936-0.4594 \\
c=0.2953-0.29589\end{array}$ & $\begin{array}{l}a=0.917-0.9184 \\
b=0.5447-0.546 \\
c=0.514-0.5154\end{array}$ & $\begin{array}{c}{[44,45,50,57,58} \\
60-62]\end{array}$ \\
\hline Cell volume $\left(\AA^{3}\right)$ & $34.02-34.061$ & $31.12-31.216$ & $32.172-32.20$ & {$[43,45,57-59]$} \\
\hline Ti-O bond length $(\AA)$ & $\begin{array}{l}1.937-1.94(4) \\
1.965-1.97(2)\end{array}$ & $\begin{array}{c}1.946-1.95(4) \\
1.980-1.984(2)\end{array}$ & - & {$[43,51,57,58]$} \\
\hline O-Ti-O bond angle & $77.7-102^{\circ}$ & $81.1-98.9^{\circ}$ & $80.7-105^{\circ}$ & {$[45,57,58,63]$} \\
\hline Specific density $\left(\mathrm{g} / \mathrm{cm}^{3}\right)$ & $3.79-3.83$ & $4.13-4.25$ & $3.99-4.170$ & {$[44,50,54,59,62]$} \\
\hline Band gap energy $(\mathrm{eV})$ & $3.20-3.30$ & $3.01-3.02$ & $3.13-3.26$ & {$[41,61,64-70]$} \\
\hline
\end{tabular}

where, $\mathrm{h}^{+}$and $\mathrm{e}^{-}$represent an unpaired electron, an electron

Table I - Properties of anatase, rutile, and brookite.

[Tabela I - Propriedades do anatásio, rutilo e brookita.] 
hole in the valence band, and an electron in the conduction band, respectively, and hv is the photon energy [74]. Rutile and anatase are photoactive, and their electrons are excited in the range of ultraviolet radiation [72,76-79]. The structure of anatase has higher photocatalytic activity than that of rutile $[53,80]$, because of its greater density of localized states and its lower electron-hole recombination rate than rutile [74].

Nanostructured $\mathrm{TiO}_{2}$ has attracted great attention in recent years because it can be used in various fields of science and technology [81-87]. At least one of the dimensions of nanostructured $\mathrm{TiO}_{2}$ polymorphs ranges from 1 to $100 \mathrm{~nm}$. Depending on the field of science and technology, materials that have one of its dimensions larger than $100 \mathrm{~nm}$ and smaller than $1000 \mathrm{~nm}$ are also referred to as nanometric or are considered submicrometric. Nanometric materials, which have a high surface area to volume ratio, comprise thin films, nanotubes, nanowires, nanostrips, nanofibers, and nanoparticles [72, 78, 88]. Nanostructured $\mathrm{TiO}_{2}$ has been described as a promising non-resorbable material for use in bone implants [41, 89, 90]. Recent studies [16, 21, 91-94] indicate that nanoscale modification of the $\mathrm{TiO}_{2}$ surface topography can positively influence cell behavior, improving implant osseointegration and aiding greater initial biointegration with surrounding tissue [95, 96]. Bone is a nanostructured compound of collagen and hydroxyapatite fibers [14, 17, 97, 98]. Hence, nanoscale surface topography mimics the topographic characteristics of the extracellular matrix of bone tissue, providing cellular support, and in some cases, adequate porosity for the process of cell adhesion, proliferation, and differentiation during the bone formation process $[29,99,100]$.

$\mathrm{TiO}_{2}$ can also be used as a coating for metal implants in tissue engineering applications. Ti osseointegration can be improved by changing the surface, such as depositing a thicker layer of $\mathrm{TiO}_{2}$ on the metal surface [101-103]. It has been reported that $\mathrm{TiO}_{2}$ coatings manufactured on the surface of a metal alloy improve corrosion resistance, biocompatibility, and promote good cell functionality and bone formation [104-107]. Composite materials also have satisfactory properties for biomaterials due to the good combination of mechanical properties and excellent biocompatibility. Studies have shown that hydroxyapatite and titanium dioxide $\left(\mathrm{HAp}-\mathrm{TiO}_{2}\right)$ composites improve mechanical resistance, osseointegration, and cell fixation due to the similarity of hydroxyapatite to various calcified tissues of vertebrates. $\mathrm{TiO}_{2}$ is able to improve the bond strength of the hydroxyapatite layer and Ti substrate, as well as corrosion resistance [108-111]. Some authors [112-116] have found that the presence of hydroxyapatite increases the resistance to corrosion, the integration of implants in bone tissue, and bone growth. In addition, the $\mathrm{HAp}-\mathrm{TiO}_{2}$ composite has excellent chemical and structural uniformity.

\section{FORMS OFSYNTHESIS USED INTHE PRODUCTION OF BIOMATERIALS}

Nanostructured $\mathrm{TiO}_{2}$ can be synthesized by several methods, including anodization [117], sol-gel [118, 119], hydrothermal [89, 120], and electrospinning [121-123]. Among these techniques, anodization and sol-gel have attracted the attention of research groups for biomedical applications, due to their simplicity, low-cost [124, 125], ability to produce nanostructures with high surface area to volume ratios [124, 126], and their ability to generate highly organized and corrosion resistant structures [12, 127]. Table II describes the characteristics of nanostructured $\mathrm{TiO}_{2}$ produced by anodization and sol-gel. Several properties of nanoscale $\mathrm{TiO}_{2}$ can significantly improve the performance of biomaterials, which can be affected by the method employed for their fabrication [41, 128-132]. Therefore, depending on the experimental conditions, synthesized materials have different characteristics [31, 133, 134], including pore structure and interconnectivity, nanotopography, and mechanical properties [135-139].

Anodization is a process that involves the application of an electric field between the metal and an anode, which triggers ionic diffusion, resulting in the formation of ordered nanotubes on the anode surface. The process is performed when a two-electrode system is exposed to alternating voltage in an electrolyte under controlled conditions [90, 168]. $\mathrm{TiO}_{2}$ nanotubes can be grown in aqueous hydrogen fluoride (HF) electrolytes containing acid [144, 150, 153] or in neutral mixtures with added fluoride salts [143, 146, 151]. The voltage applied in the anodization process affects the $\mathrm{TiO}_{2}$ nanotube diameter. Several studies [142, 147-149, 152] reported that the $\mathrm{TiO}_{2}$ nanotube diameter increases in response to increasing voltage (Fig. 2). In addition, as the applied voltage is increased, the surface morphology changed from particulate to tubular. Recently, other studies [105, 140, 141] also demonstrated that different $\mathrm{TiO}_{2}$ nanotube diameters can be obtained by controlling the voltage applied in the anodization process. $\mathrm{TiO}_{2}$ nanotube diameter can also be influenced by the type of electrolyte. In an early study [154], titanium metal sheet in phosphate and fluorine electrolytes was used to form nanotubes; the results indicated that the nanotube diameters were 50 and $100 \mathrm{~nm}$ using $\mathrm{NH}_{4} \mathrm{~F}$ and $\mathrm{H}_{3} \mathrm{PO}_{4}$ electrolytes, respectively. In another study [145], $\mathrm{TiO}_{2}$ nanotubes were produced by anodizing titanium metal sheet in $\mathrm{NH}_{4} \mathrm{~F}$ and $\mathrm{H}_{3} \mathrm{PO}_{4}$ electrolyte; the authors also stated that changing the electrolyte from $\mathrm{NH}_{4} \mathrm{~F}$ to $\mathrm{H}_{3} \mathrm{PO}_{4}$ caused the nanotube diameter to increase from 174.2 to $235.3 \mathrm{~nm}$.

In the sol-gel method, a solution transitions to a gel state that can solidify into an interconnected network of particles. The solution may be formed by means of hydrolysis and polymerization reactions $[124,126]$. The firing temperature of gels affects the morphology of nanostructured $\mathrm{TiO}_{2}$. Several studies $[56,155,156,158-161,163-165,167]$ reported that firing at up to $550{ }^{\circ} \mathrm{C}$ resulted in spherical particles, and only anatase phase was found. At temperatures above $600{ }^{\circ} \mathrm{C}$, larger particles and development of the rutile phase were observed [56]. Peaks of the rutile phase observed after heating at $700{ }^{\circ} \mathrm{C}$ were attributed to anatase to rutile phase transition $[157,162,163]$. The morphology of 
Table II - Processing methods of nanostructured $\mathrm{TiO}_{2}$. [Tabela II - Métodos de síntese de $\mathrm{TiO}_{2}$ nanoestruturado.]

\begin{tabular}{|c|c|c|c|c|c|}
\hline Method & $\begin{array}{l}\text { Calcination } \\
\text { temperature }\end{array}$ & Morphology & Phase & Size & Ref. \\
\hline Anodization of $\mathrm{Ti}$ & $530^{\circ} \mathrm{C}$ & Nanotube & Anatase & Nanotube diameter: $70-110 \mathrm{~nm}$ & [105] \\
\hline Anodization of $\mathrm{Ti}$ & $450^{\circ} \mathrm{C}$ & Nanotube & Anatase & Nanotube diameter: $160-200 \mathrm{~nm}$ & [140] \\
\hline Anodization of $\mathrm{Ti}$ & $420^{\circ} \mathrm{C}$ & Nanotube & Anatase & Nanotube diameter: $45-60 \mathrm{~nm}$ & [141] \\
\hline Anodization of $\mathrm{Ti}$ & $450^{\circ} \mathrm{C}$ & Nanotube & Anatase & Nanotube diameter: $26-115 \mathrm{~nm}$ & [142] \\
\hline Anodization of $\mathrm{Ti}$ & $450^{\circ} \mathrm{C}$ & Nanotube & Anatase & Nanotube diameter: $65.7-87 \mathrm{~nm}$ & [143] \\
\hline Anodization of $\mathrm{Ti}$ & $750^{\circ} \mathrm{C}$ & Nanotube & Anatase, rutile & Nanotube diameter: $50-70 \mathrm{~nm}$ & [144] \\
\hline Anodization of $\mathrm{Ti}$ & - & Nanotube & - & Nanotube diameter: $174.2-235.3 \mathrm{~nm}$ & [145] \\
\hline Anodization of $\mathrm{Ti}$ & $450^{\circ} \mathrm{C}$ & Nanotube & Anatase & Nanotube diameter: $45 \mathrm{~nm}$ & [146] \\
\hline Anodization of $\mathrm{Ti}$ & $500^{\circ} \mathrm{C}$ & Nanotube & Anatase & Nanotube diameter: $30-90 \mathrm{~nm}$ & [147] \\
\hline Anodization of $\mathrm{Ti}$ & $480^{\circ} \mathrm{C}$ & Nanotube & Anatase & Nanotube diameter: $40-80 \mathrm{~nm}$ & [148] \\
\hline Anodization of $\mathrm{Ti}$ & $450^{\circ} \mathrm{C}$ & Nanotube & Anatase & Nanotube diameter: $20-120 \mathrm{~nm}$ & [149] \\
\hline Anodization of $\mathrm{Ti}$ & $500^{\circ} \mathrm{C}$ & Nanotube & Anatase & Nanotube diameter: 80-100 nm & [150] \\
\hline Anodization of $\mathrm{Ti}$ & $580^{\circ} \mathrm{C}$ & Nanotube & Anatase & Nanotube diameter: $165 \mathrm{~nm}$ & [151] \\
\hline Anodization of $\mathrm{Ti}$ & - & Nanotube & - & Nanotube diameter: $15-120 \mathrm{~nm}$ & [152] \\
\hline Anodization of $\mathrm{Ti}$ & $480^{\circ} \mathrm{C}$ & Nanotube & Anatase, rutile & Nanotube diameter: $40-110 \mathrm{~nm}$ & [153] \\
\hline Anodization of $\mathrm{Ti}$ & - & Nanotube & - & Nanotube diameter: $50-100 \mathrm{~nm}$ & [154] \\
\hline Sol-gel & $400^{\circ} \mathrm{C}$ & Nanoparticle & Anatase & Crystallite size: $11-22 \mathrm{~nm}$ & [155] \\
\hline Sol-gel & $500^{\circ} \mathrm{C}$ & Nanoparticle & Anatase & Particle size: $51.98 \mathrm{~nm}$ & [156] \\
\hline Sol-gel & $800^{\circ} \mathrm{C}$ & Nanoparticle & Anatase, rutile & Particle size: $47 \mathrm{~nm}$ & [157] \\
\hline Sol-gel & $400^{\circ} \mathrm{C}$ & Nanoparticle & Anatase & Crystallite size: $17.7 \mathrm{~nm}$ & [158] \\
\hline Sol-gel & $400^{\circ} \mathrm{C}$ & Nanoparticle & Anatase & Crystallite size: $13.8 \mathrm{~nm}$ & [159] \\
\hline Sol-gel & $450^{\circ} \mathrm{C}$ & Nanoparticle & Anatase & Crystallite size: $10 \mathrm{~nm}$ & [160] \\
\hline Sol-gel & $500^{\circ} \mathrm{C}$ & Nanoparticle & Anatase & Crystallite size: $19.3 \mathrm{~nm}$ & [161] \\
\hline Sol-gel & $550^{\circ} \mathrm{C}$ & Nanoparticle & Anatase & Particle size: $0.8 \mu \mathrm{m}$ & [162] \\
\hline Sol-gel & $950{ }^{\circ} \mathrm{C}$ & Nanoparticle & Rutile & Particle size: $1.0 \mu \mathrm{m}$ & [162] \\
\hline Sol-gel & $700^{\circ} \mathrm{C}$ & Nanoparticle & Anatase, rutile & Crystallite size: $80 \mathrm{~nm}$ & [163] \\
\hline Sol-gel & $500^{\circ} \mathrm{C}$ & Nanoparticle & Anatase & Crystallite size: $20 \mathrm{~nm}$ & [163] \\
\hline Sol-gel & $400^{\circ} \mathrm{C}$ & Nanoparticle & Anatase & Crystallite size: $3.9 \mathrm{~nm}$ & [164] \\
\hline Sol-gel & $450^{\circ} \mathrm{C}$ & Nanoparticle & Anatase & Particle size: $50-100 \mathrm{~nm}$ & [165] \\
\hline Sol-gel & $350^{\circ} \mathrm{C}$ & Nanoparticle & Anatase & Particle size: $30-90 \mathrm{~nm}$ & [166] \\
\hline Sol-gel & $400^{\circ} \mathrm{C}$ & Nanoparticle & Anatase & Crystallite size: $27.4 \mathrm{~nm}$ & [167] \\
\hline Sol-gel & $400^{\circ} \mathrm{C}$ & Nanoparticle & Anatase & Crystallite size: $13.7 \mathrm{~nm}$ & {$[56]$} \\
\hline Sol-gel & $600^{\circ} \mathrm{C}$ & Nanoparticle & Anatase, rutile & Crystallite size: $25.8 \mathrm{~nm}$ & [56] \\
\hline
\end{tabular}

nanostructures can also be influenced by the ratio between quantities of reactants, notably the ratio of ceramic precursor to water. Nanocrystalline titanium dioxide powders were synthesized by the sol-gel method, varying the rate of hydrolysis [163]. The nanoparticles were synthesized by hydrolysis using as precursor $20 \mathrm{~mL}$ of titanium isopropoxide mixed with $100 \mathrm{~mL}$ of ethanol and different amounts of water to control the hydrolysis rate. The results indicated that powder prepared with $2 \mathrm{~mL}$ of water contained very fine anatase crystals and quasi-spherical nanoparticles. Upon increasing the amount of water to 5 and $10 \mathrm{~mL}$, spherical and homogeneous structures were obtained in response to the increase in hydrolysis rate, which proves that increasing the amount of water facilitates particle formation [163]. $\mathrm{TiO}_{2}$ nanoparticles were also produced by the sol-gel method using $0.5 \mathrm{~g}$ of titanium tetrabutoxide, $50 \mathrm{~mL}$ of diethylene 


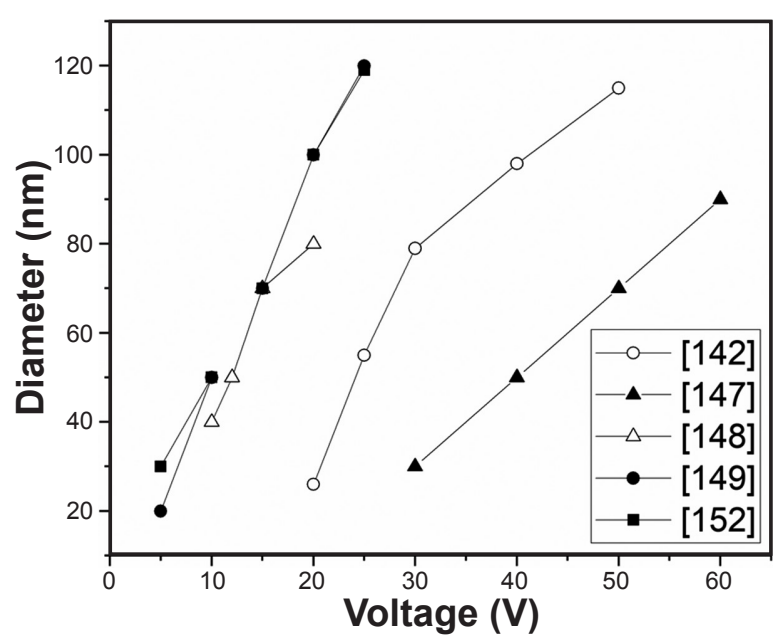

Figure 2: Influence of applied voltage on the diameter of $\mathrm{TiO}_{2}$ nanotubes obtained by anodization.

[Figura 2: Influência da tensão aplicada no diâmetro dos nanotubos de $\mathrm{TiO}_{2}$ obtidos por anodização.]

glycol, and different amounts of water; it was found that, as the amount of water increased from 0.5 to $5 \mathrm{~mL}$, the mean particle diameter decreased from 550 to $250 \mathrm{~nm}$ [56].

\section{STUDIES OF THE BIOLOGICAL PROPERTIES OF NANOSTRUCTURED $\mathrm{TiO}_{2}$ USED IN BIOMEDICINE}

As mentioned earlier herein, nanostructured $\mathrm{TiO}_{2}$ has attracted the attention of researchers for the development of biomaterials [169-173] and implant technology [6, 71, 174-178]. Studies have shown that the cellular response is affected by the material's topography [179-184]. Cells respond positively to nanotopography, with changes in cell morphology, cytoskeleton organization, and proliferation. This means that nanostructuring plays an important role in cellular interaction $[15,31]$. Table III lists several studies on nanostructured $\mathrm{TiO}_{2}$, revealing how nanoscale topography and crystal structure affect cell-surface interactions. It has been reported [31, 191, 204-208] that nanotubular surfaces produced by anodization are able to display cellular responses and simulate a bioactive matrix for cellular accommodation. This is due to increased surface wettability and selective adsorption of proteins in body fluids [12, 47]. $\mathrm{TiO}_{2}$ nanotubes have good biocompatibility due to their low cytotoxicity, good stability, and cytocompatibility, including adhesion, proliferation, and differentiation of osteoblasts with high surface area to volume ratio [209]. In this context, the $\mathrm{TiO}_{2}$ nanotube surface favors osteoblast adhesion and exhibits a strong ability to bind to bone [210]. Moreover, it facilitates fluid exchange, which is responsible for improving molecular signaling in bone remodeling and functioning characteristics [211].

Several properties can affect cellular responses and protein adsorption in biological systems $[47,212]$. Hydrophilicity and surface roughness [101, 213-216], associated with the high surface area to volume ratio characteristic of nanostructured materials, have been shown to promote high cell adhesion, proliferation, and differentiation [217-220]. Numerous studies $[16,17,174,185,189-191,195]$ have shown that nanoscale $\mathrm{TiO}_{2}$ nanotube surfaces present uniform structure, roughness, and hydrophilicity, with contact angles smaller than $55^{\circ}$. Porosity is essential for bone implants, being responsible for the formation of bone tissue, proliferation of osteoblasts, vascularization, and bioactivity. In addition, a porous structure provides good mechanical stability due to the better mechanical interlock between the biomaterial implant and the natural bone [203, 221, 222]. Some studies [223-227] report that a porous structure significantly accelerates cell adhesion and bone growth capacity. The pores must be interconnected with dimensions between 200 to $500 \mu \mathrm{m}$ to meet the migration and transport requirements of the cell, providing adequate space and permeability for viable bone formation in nanostructured $\mathrm{TiO}_{2}$.

Nanoscale topography has been shown to be the ideal size for the best osteoblast function [194, 228, 229]. According to [198], osteoblast adhesion and propagation was improved by the topography of $\mathrm{TiO}_{2}$ nanotubes, forming an interconnected cell structure. The nanoscale structure hastened the growth rate of MC3T3-E1 osteoblastic cells by up to $300 \%$ to $400 \%$. Several studies $[149,174,185,187$, $192,194,195]$ also found that cells attached to the surface of nanotubes became increasingly elongated and formed small filopodia, suggesting that they could be used for orthopedic purposes. Over the years, several researchers $[144,188$, $190,192,193,196]$ have found that the surfaces of $\mathrm{TiO}_{2}$ nanotubes immersed in simulated body fluid (SBF) favor the formation of osteoblast-like hydroxyapatite, which is critical for osseointegration, with strong adhesion and binding [230, 231]. As noted by several authors [16, 35, 198, 232, $233]$, the anatase and rutile phases provide adequate atomic arrangements for the formation of hydroxyapatite. Anatase provides the best effects for cell adhesion, proliferation, and differentiation because it is more chemically reactive. Nevertheless, the rutile phase is also interesting due to its higher modulus of elasticity, hardness, and adhesive strength than anatase. Hence, the anatase phase and the mixed anatase-rutile phase are beneficial for cell growth, due to their hydroxyapatite mineralization and increased corrosion resistance. It has been reported that the crystal structure of anatase facilitated osteoblast growth and exhibited structural stability in physiological medium $[149,174,186,188,190$, 192, 193, 196, 198]. Moreover, it has been suggested that osteoblasts disseminate better in anatase-rutile mixtures [186, 193, 195, 234].

Alkaline phosphatase (ALP) activity serves to analyze the functionality of cells on a surface. $\mathrm{TiO}_{2}$ nanotubes were produced through the anodization process and evaluated for bone cell interactions using ALP [195]. During each day of analysis, the cells showed a filamentous network-like structure scattered over the entire surface. It was reported that after the $5^{\text {th }}$ day of cultivation, the ALP level exceeded the titanium substrate [195]. It has been pointed out that ALP in osteoblasts gradually increased on the surface of $\mathrm{TiO}_{2}$ nanotubes as the number of days of cultivation increased, 
Table III - Studies of the biological properties of nanostructured $\mathrm{TiO}_{2}$. [Tabela III - Estudos das propriedades biológicas do $\mathrm{TiO}_{2}$ nanoestruturado.]

\begin{tabular}{|c|c|c|c|c|c|}
\hline Method & Phase & Type of cell & Type of test & Cell response & Ref. \\
\hline Anodization & - & MG-63 & $\begin{array}{l}\text { Contact angle, atomic force } \\
\text { microscopy, in vitro assay }\end{array}$ & $\begin{array}{l}\text { Hydrophilicity; cells exhibit rounded morphology with small } \\
\text { filopodia on the surface; high adhesion of MG-63 cells to } \mathrm{TiO}_{2} \\
\text { nanotubes }\end{array}$ & [185] \\
\hline Anodization & Anatase & MC3T3 & $\begin{array}{l}\text { Contact angle, alkaline } \\
\text { phosphatase (ALP) activity }\end{array}$ & $\begin{array}{l}\text { Hydrophilicity; after } 7 \text { days of culture, ALP of MC3T3 grown } \\
\text { in different samples exceeded the Ti substrate }\end{array}$ & [17] \\
\hline Anodization & Anatase & G8080 & Contact angle, cell proliferation & Hydrophilicity, with cells favoring cell proliferation & [186] \\
\hline Anodization & $\begin{array}{l}\text { Anatase } \\
+ \text { rutile }\end{array}$ & G8080 & Contact angle, cell proliferation & $\begin{array}{l}\mathrm{TiO}_{2} \text { nanotubes less hydrophilic, with more stimulated } \\
\text { proliferation, compared to that containing only anatase phase }\end{array}$ & [186] \\
\hline Anodization & - & MC3T3-E1 & $\begin{array}{l}\text { Contact angle, atomic force } \\
\text { microscopy, in vivo }\end{array}$ & $\begin{array}{l}\text { Hydrophilicity; surface grown osteoblastic cells exhibit } \\
\text { a well-distributed cytoskeleton organization; in vivo tests } \\
\text { indicate that the anodized surface of the implant promotes } \\
\text { osseointegration and greater bone binding strength than pure } \\
\text { Ti substrate }\end{array}$ & [187] \\
\hline Anodization & Anatase & hBMSCs & $\begin{array}{l}\text { Contact angle, immersion in } \\
\text { SBF, in vitro assay }\end{array}$ & $\begin{array}{l}\text { Hydrophilicity; formation of hydroxyapatite after } 21 \text { days in } \\
\text { simulated body fluid (SBF) }\end{array}$ & [188] \\
\hline Anodization & Anatase & - & Contact angle & Hydrophilicity & [189] \\
\hline Anodization & Anatase & MC3T3-E1 & $\begin{array}{l}\text { Contact angle, atomic force } \\
\text { microscopy, immersion in SBF }\end{array}$ & $\begin{array}{l}\text { Hydrophilicity; formation of hydroxyapatite after } 12 \text { days in } \\
\qquad \text { SBF }\end{array}$ & [190] \\
\hline Anodization & $\begin{array}{l}\text { Anatase } \\
+ \text { rutile }\end{array}$ & SAOS-2 & $\begin{array}{l}\text { Contact angle, cell proliferation, } \\
\text { fluorescence microscopy }\end{array}$ & $\begin{array}{l}\text { Hydrophilicity; cells adhere to all the surfaces; seeded } \\
\text { osteoblasts promote adhesion }\end{array}$ & [191] \\
\hline Anodization & $\begin{array}{l}\text { Anatase } \\
+ \text { rutile }\end{array}$ & - & Immersion in SBF & Formation of hydroxyapatite after 7 and 14 days in SBF & [144] \\
\hline Anodization & Anatase & G-292 & $\begin{array}{l}\text { Scanning electron microscopy, } \\
\text { immersion in SBF }\end{array}$ & $\begin{array}{l}\text { Cells attached to the surface of nanotubes became increasingly } \\
\text { elongated and formed filopodia; formation of hydroxyapatite } \\
\text { after } 5 \text { and } 10 \text { days in SBF }\end{array}$ & [192] \\
\hline Anodization & Anatase & MC3T3-E1 & Immersion in SBF, in vitro assay & $\begin{array}{l}\text { Formation of hydroxyapatite after } 3 \text { days in SBF, with size } \\
\text { increasing as a function of immersion time }\end{array}$ & [193] \\
\hline Anodization & $\begin{array}{l}\text { Anatase } \\
+ \text { rutile }\end{array}$ & MC3T3-E1 & Immersion in SBF, in vitro assay & $\begin{array}{l}\text { Formation of hydroxyapatite after } 3 \text { days in SBF; a greater } \\
\text { amount of hydroxyapatite was formed in the synthesized } \\
\text { sample containing the anatase and rutile mixture than in the } \\
\text { sample containing only anatase }\end{array}$ & [193] \\
\hline Anodization & $\begin{array}{l}\text { Anatase } \\
+ \text { rutile }\end{array}$ & MC3T3-E1 & $\begin{array}{l}\text { Atomic force microscopy, } \\
\text { confocal laser scanning } \\
\text { microscopy, Alizarin Red } \\
\text { staining protocol }\end{array}$ & $\begin{array}{l}\text { Cells grown on nanotubes disperse better and put forth more } \\
\text { filopodia than smooth layers; cytoskeleton of osteoblasts } \\
\text { grown on anatase display a regular arrangement }\end{array}$ & [149] \\
\hline Anodization & - & HSCs & $\begin{array}{l}\text { Scanning electron microscopy, } \\
\text { cell proliferation }\end{array}$ & $\begin{array}{l}\text { Cells normally disperse on nanotubes, forming several } \\
\text { filopodia }\end{array}$ & [194] \\
\hline Anodization & Anatase & MC3T3-E1 & $\begin{array}{l}\text { Atomic force microscopy, } \\
\text { contact angle, alkaline } \\
\text { phosphatase (ALP) activity }\end{array}$ & $\begin{array}{l}\text { Osteoblasts grown on the surface of } \mathrm{TiO}_{2} \text { nanotubes } \\
\text { showed several filopodia extending along the main edges; } \\
\text { hydrophilicity; extremely elongated cell morphology and high } \\
\text { levels of alkaline phosphatase }\end{array}$ & [174] \\
\hline Anodization & $\begin{array}{l}\text { Anatase } \\
+ \text { rutile }\end{array}$ & $\mathrm{OPC} 1$ & $\begin{array}{l}\text { Atomic force microscopy, } \\
\text { contact angle, alkaline } \\
\text { phosphatase activity }\end{array}$ & $\begin{array}{l}\text { Hydrophilicity; filamentous network-like structure with } \\
\text { excellent cell to cell connection; ALP in osteoblasts was high } \\
\text { after the } 5^{\text {th }} \text { day of culture }\end{array}$ & [195] \\
\hline Anodization & Anatase & - & Immersion in SBF & Formation of hydroxyapatite after 2 days in SBF & [196] \\
\hline Anodization & - & G8080 & $\begin{array}{l}\text { Alkaline phosphatase activity, in } \\
\text { vitro assays }\end{array}$ & $\begin{array}{l}\text { Approximately } 50 \% \text { increase in } \mathrm{ALP} \text { levels on nanotube } \\
\text { surfaces after } 3 \text { weeks of culture; } \mathrm{TiO}_{2} \text { nanotubes did not cause } \\
\text { chronic inflammation or fibrosis under in vivo conditions }\end{array}$ & [197] \\
\hline Anodization & Anatase & MC3T3-E1 & $\begin{array}{l}\text { Alkaline phosphatase activity, } \\
\text { environmental scanning electron } \\
\text { microscopy }\end{array}$ & $\begin{array}{l}\text { Cells grown on } \mathrm{TiO}_{2} \text { nanotubes presented filopodia; cell } \\
\text { growth accelerated by up to } 300-400 \%\end{array}$ & [198] \\
\hline Sol-gel & Anatase & - & Atomic force microscopy & Ca-doped $\mathrm{TiO}_{2}$ gels showed good adhesion & [199] \\
\hline Sol-gel & Anatase & - & Immersion in SBF & Formation of hydroxyapatite after 28 days in SBF & [200] \\
\hline Sol-gel & Anatase & - & Immersion in SBF & Formation of hydroxyapatite after 2 days in SBF & [201] \\
\hline Sol-gel & Anatase & - & Immersion in SBF & $\begin{array}{l}\text { Amount of hydroxyapatite formed after } 14 \text { days in SBF } \\
\text { was greater in the gels containing only anatase than in those } \\
\text { containing anatase and rutile mixture }\end{array}$ & [202] \\
\hline Sol-gel & $\begin{array}{l}\text { Anatase } \\
+ \text { rutile }\end{array}$ & - & Immersion in SBF & Formation of hydroxyapatite after 14 days in SBF & [202] \\
\hline Sol-gel & - & - & Immersion in SBF & Formation of hydroxyapatite after 3 to 6 days in SBF & [203] \\
\hline
\end{tabular}


showing excellent cell-to-cell binding [15, 17, 197, 198]. $\mathrm{TiO}_{2}$ gels produced by the sol-gel technique can potentially be used in biomedical applications. The formation of hydroxyapatite immersed in SBF in amorphous and crystalline $\mathrm{TiO}_{2}$ gels was investigated $[202,203]$. $\mathrm{TiO}_{2}$ gels with an amorphous structure did not induce the formation of hydroxyapatite on their surfaces in simulated body fluid, while gels with anatase or mixed anatase-rutile induced hydroxyapatite formation on their surfaces. Some authors [199-201] have discussed the influence of doping elements via the sol-gel method. They found that doping with calcium ions stimulates bioactivity, improving the formation of hydroxyapatite on the surface of nanostructured $\mathrm{TiO}_{2}$.

For in vivo evaluations, it is essential for nanostructured biomaterials to be biocompatible and prevent inflammatory response. Such studies can be performed using animal models that can mimic the growth environment and bone infection. Several animals such as rats and pigs can be used for in vivo experiments, depending on research needs, proper bone size, ease of handling, and low costs [16, 235238]. Popat et al. [197] synthesized $\mathrm{TiO}_{2}$ nanotubes by anodization and used the G8080 cell line. They assessed in vivo biocompatibility on surfaces of subcutaneous implants in male Lewis rats and made a histological analysis of the tissue around the implants after 4 weeks. The results indicated that $\mathrm{TiO}_{2}$ nanotubes were uniform and caused no inflammation, and that the tissue was normal and healthy. $\mathrm{Li}$ et al. [187] evaluated the behavior of MC3T3-E1 osteoblasts in experiments with Sprague Dawley rats. After 4 weeks they observed that the anodized implant surface promoted osseointegration. Their study demonstrated the good biological performance of $\mathrm{TiO}_{2}$ nanotubes, which are able to withstand the forces they undergo during and after insertion into the bone.

\section{CONCLUSIONS}

The studies presented in this review of nanostructured $\mathrm{TiO}_{2}$ demonstrate a promising perspective for tissue engineering, given the possible use of this nanomaterial in bone reconstruction. Biological responses can be controlled by modifying fabrication procedures, e.g., by applying variations in voltage, electrolytes, and using heattreatments. Studies have shown that nanostructured $\mathrm{TiO}_{2}$ immersed in simulated body fluid favors the formation of osteoblast-like hydroxyapatite. Equally important, in vivo assays have confirmed the biocompatibility and absence of inflammatory response of $\mathrm{TiO}_{2}$ nanotubes, which is a material with great potential for application in bone regeneration.

\section{ACKNOWLEDGEMENTS}

The authors thank the research funding agencies CAPES (Finance Code 001: scholarship granted to Mrs. Ione Amorim Bezerra Neta) and CNPq (project 308822/2018-8 and 420004/2018-1).

\section{REFERENCES}

[1] J.I. Dawson, R.O. Oreffo, Arch. Biochem. Biophys. 473 (2008) 124.

[2] X. Lin, S. Yang, K. Lai, H. Yang, T.J. Webster, L. Yang, Nanomedicine 13 (2017) 123.

[3] A.R. Amini, C.T. Laurencin, S.P. Nukavarapu, Crit. Rev. Biomed. Eng. 40 (2012) 363.

[4] J.R. Venugopal, S. Low, A.T. Choon, A.B. Kumar, S. Ramakrishna, Artif. Organs 32 (2008) 388.

[5] S. Balasubramanian, B. Gurumurthy, A. Balasubramanian, Int. J. Pharm. Sci. Res. 8 (2017) 4950.

[6] E.M. Christenson, K.S. Anseth, J.J. van den Beucken, C.K. Chan, B. Ercan, J.A. Jansen, C.T. Laurencin, W.J. Li, R. Murugan, L.S. Nair, J. Orthop. Res. 25 (2007) 11.

[7] L. Hermansson, J. Korean Ceram. Soc. 55 (2018) 95.

[8] M. Jäger, H. Jennissen, F. Dittrich, A. Fischer, H. Köhling, Materials 10 (2017) 1302.

[9] N. Shadjou, M. Hasanzadeh, Mater. Technol. 31 (2016) 806.

[10] M. Vallet-Regí, D. Arcos, Curr. Nanosci. 2 (2006) 179. [11] J. Venugopal, M.P. Prabhakaran, Y. Zhang, S. Low, A.T. Choon, S. Ramakrishna, Philos. Trans. Royal Soc. A 368 (2010) 2065.

[12] M. Kulkarni, A. Mazare, E. Gongadze, Š. Perutkova, V. Kralj-Iglič, I. Milošev, P. Schmuki, A. Iglič, M. Mozetič, Nanotechnology 26 (2015) 62002.

[13] J. Souza, L. Bins-Ely, M. Sordi, R. Magini, C. Aparicio, T. Shokuhfar, L. Cooper, in "Nanostructured biomaterials for cranio-maxillofacial and oral applications", J. Souza, D. Hotza, B. Henriques, A. Boccaccini (Eds.), Elsevier (2018) 13.

[14] T. Xu, N. Zhang, H.L. Nichols, D. Shi, X. Wen, Mater. Sci. Eng. C 27 (2007) 579.

[15] K.S. Brammer, C.J. Frandsen, S. Jin, Trends Biotechnol. 30 (2012) 315.

[16] L. Lv, Y. Liu, P. Zhang, X. Zhang, J. Liu, T. Chen, P. Su, H. Li, Y. Zhou, Biomaterials 39 (2015) 193.

[17] G. Wang, Y. Wan, B. Ren, Z. Liu, Mater. Sci. Eng. C 95 (2019) 114.

[18] P. Gkomoza, M. Vardavoulias, D. Pantelis, C. Sarafoglou, Surf. Coat. Technol. 357 (2019) 748.

[19] J.I. Lim, B. Yu, K.M. Woo, Y.-K. Lee, Appl. Surf. Sci. 255 (2008) 2456.

[20] S. Mondal, G. Hoang, P. Manivasagan, H. Kim, J. Oh, Ceram. Int. 46, 3 (2019) 3443.

[21] L. Salou, A. Hoornaert, G. Louarn, P. Layrolle, Acta Biomater. 11 (2015) 494.

[22] Y.-T. Sul, Int. J. Nanomedicine 5 (2010) 87.

[23] R. Valiev, I. Sabirov, E. Zemtsova, E. Parfenov, L. Dluhoš, T. Lowe, in "Titanium in medical and dental applications", F. Froes, M. Qian (Eds.), Elsevier (2018) 393. [24] X.-M. Zhuang, B. Zhou, K.-F. Yuan, Biomed. Pharmacother. 112 (2019) 108649.

[25] X. Chen, A. Selloni, Chem. Rev. 114, 19 (2014) 9281.

[26] G. Fostad, B. Hafell, A. Førde, R. Dittmann, R. Sabetrasekh, J. Will, J. Ellingsen, S. Lyngstadaas, H. 
Haugen, J. Eur. Ceram. Soc. 29 (2009) 2773.

[27] H. Haugen, J. Will, A. Köhler, U. Hopfner, J. Aigner, E. Wintermantel, J. Eur. Ceram. Soc. 24 (2004) 661.

[28] T. Kasuga, H. Kondo, M. Nogami, J. Cryst. Growth 235 (2002) 235.

[29] K. Lee, A. Mazare, P. Schmuki, Chem. Rev. 114 (2014) 9385.

[30] H. Nygren, P. Tengvall, I. Lundström, J. Biomed. Mater. Res. 34 (1997) 487.

[31] Y. Fu, A. Mo, Nanoscale Res. Lett. 13 (2018) 187.

[32] M. Garcia-Lobato, A. Mtz-Enriquez, C. Garcia, M. Velazquez-Manzanares, F. Avalos-Belmontes, R. RamosGonzalez, L. Garcia-Cerda, Appl. Surf. Sci. 484 (2019) 975. [33] K. Das, S. Bose, A. Bandyopadhyay, J. Biomed. Mater. Res. A 90 (2009) 225.

[34] Y. Peng, Y. Song, Q. Wang, Y. Hu, Y. He, D. Ren, L. Wu, S. Liu, H. Cong, H. Zhou, Int. J. Biol. Macromol. 127 (2019) 48.

[35] N. Wang, H. Li, W. Lü, J. Li, J. Wang, Z. Zhang, Y. Liu, Biomaterials 32 (2011) 6900.

[36] D.B. Warheit, Toxicol. Lett. 220 (2013) 193.

[37] J. Wen, X. Li, W. Liu, Y. Fang, J. Xie, Y. Xu, Chinese J. Catal. 36 (2015) 2049.

[38] J. Feng, X. Yan, K. Lin, S. Wang, J. Luo, Y. Wu, Mater. Lett. 214 (2018) 178.

[39] I. Shepa, E. Mudra, M. Vojtko, P. Tatarko, V. Girman, O. Milkovic, T. Sopcak, V. Medvecka, J. Dusza, Ceram. Int. 44 (2018) 17925.

[40] V. Simi, N. Rajendran, Mater. Charact. 129 (2017) 67. [41] A. Tan, B. Pingguan-Murphy, R. Ahmad, S. Akbar, Ceram. Int. 38 (2012) 4421.

[42] K.-R. Zhu, M.-S. Zhang, J.-M. Hong, Z. Yin, Mater. Sci. Eng. A 403 (2005) 87.

[43] N. Rahimi, R.A. Pax, E.M. Gray, Prog. Solid. State Ch. 44 (2016) 86.

[44] O. Carp, C.L. Huisman, A. Reller, Prog. Solid. State Ch. 32 (2004) 33.

[45] V. Zainullina, V. Zhukov, M. Korotin, J. Photochem. Photobiol. C 22 (2015) 58.

[46] M. Kulkarni, A. Mazare, E. Gongadze, S. Perutkova, V. Kralj-Iglic, I. Milosev, P. Schmuki, A. Iglic, M. Mozetic, Nanotechnology 26 (2015) 62002.

[47] K.M. Kummer, E. Taylor, T.J. Webster, Nanosci. Nanotechnol. Lett. 4 (2012) 483.

[48] V. Binas, D. Venieri, D. Kotzias, G. Kiriakidis, J. Materiomics 3 (2017) 3.

[49] S. Miszczak, B. Pietrzyk, Ceram. Int. 41 (2015) 7461.

[50] D.A. Hanaor, C.C. Sorrell, J. Mater. Sci. 46 (2011) 855.

[51] M. Pelaez, N.T. Nolan, S.C. Pillai, M.K. Seery, P.

Falaras, A.G. Kontos, P.S. Dunlop, J.W. Hamilton, J.A.

Byrne, K. O’Shea, Appl. Catal. B 125 (2012) 331.

[52] I. Ali, M. Suhail, Z.A. Alothman, A. Alwarthan, RSC Adv. 8 (2018) 30125.

[53] M. Erol, O. Ertugrul, Ceram. Int. 44 (2018) 2991.

[54] H. Lin, L. Li, M. Zhao, X. Huang, X. Chen, G. Li, R. Yu, J. Am. Chem. Soc. 134 (2012) 8328.

[55] N.A. Ramos-Delgado, M.Á. Gracia-Pinilla, R.V.
Mangalaraja, K. O'Shea, D.D. Dionysiou, Nanotechnol. Rev. 5 (2016) 467.

[56] L. Wang, Y. Cai, L. Song, W. Nie, Y. Zhou, P. Chen, Colloids Surf. A Physicochem. Eng. Asp. 461 (2014) 195.

[57] I. Ali, M. Suhail, Z.A. Alothman, A. Alwarthan, RSC Adv. 8 (2018) 30125.

[58] S.M. Gupta, M. Tripathi, Chin. Sci. Bull. 56 (2011) 1639.

[59] R. Singh, S. Dutta, Fuel 220 (2018) 607.

[60] Z. Li, Z. Yao, A.A. Haidry, T. Plecenik, L. Xie, L. Sun, Q. Fatima, Int. J. Hydrog. Energy 43, 45 (2018) 21114.

[61] R. Verma, J. Gangwar, A.K. Srivastava, RSC Adv. 7 (2017) 44199.

[62] X. Yan, X. Chen, in "Encyclopedia of inorganic and bioinorganic chemistry", John Wiley Sons (2015) 1.

[63] S. Livraghi, M. Rolando, S. Maurelli, M. Chiesa, M.C. Paganini, E. Giamello, J. Phys. Chem. C 118 (2014) 22141.

[64] H. Abdullah, M.M.R. Khan, H.R. Ong, Z. Yaakob, J. CO2 Util. 22 (2017) 15.

[65] M.R. Al-Mamun, S. Kader, M.S. Islam, M.Z.H. Khan, J. Environ. Chem. Eng. 7, 5 (2019) 103248.

[66] R. Fatima, M.N. Afridi, V. Kumar, J. Lee, I. Ali, K.-H. Kim, J.-O. Kim, J. Clean. Prod. 231 (2019) 899.

[67] N. Khalid, A. Majid, M.B. Tahir, N. Niaz, S. Khalid, Ceram. Int. 43 (2017) 14552.

[68] A. Mishra, A. Mehta, S. Basu, J. Environ. Chem. Eng. 6 (2018) 6088.

[69] Z. Shayegan, C.-S. Lee, F. Haghighat, Chem. Eng. J. 334 (2018) 2408.

[70] A. Zaleska, Recent Pat. Eng. 2 (2008) 157.

[71] T. Li, K. Gulati, N. Wang, Z. Zhang, S. Ivanovski, Mater. Sci. Eng. C 88 (2018) 182.

[72] X. Zhao, L. Huang, Ceram. Int. 43 (2017) 3975.

[73] R. Ahmad, Z. Ahmad, A.U. Khan, N.R. Mastoi, M. Aslam, J. Kim, J. Environ. Chem. Eng. 4 (2016) 4143.

[74] K. Cowden, M.F. Dias-Netipanyj, K.C. Popat, Nanomedicine (2019).

[75] U.I. Gaya, A.H. Abdullah, J. Photochem. Photobiol. C 9 (2008) 1.

[76] M. Qamar, B. Merzougui, D. Anjum, A.S. Hakeem, Z.H. Yamani, D. Bahnemann, Catal. Today 230 (2014) 158. [77] X. Qu, Y. Yi, F. Qiao, M. Liu, X. Wang, R. Yang, H. Meng, L. Shi, F. Du, Ceram. Int. 44 (2018) 1348.

[78] L. Rožić, S. Petrović, D. Lončarević, B. Grbić, N. Radić, S. Stojadinović, V. Jović, J. Lamovec, Ceram. Int. 45 (2019) 2361.

[79] Z. Tan, K. Sato, S. Ohara, Adv. Powder Technol. 26 (2015) 296.

[80] T. Peng, D. Zhao, H. Song, C. Yan, J. Mol. Catal. A Chem. 238 (2005) 119.

[81] A.J. Haider, R.H. Al-Anbari, G.R. Kadhim, C.T. Salame, Energy Procedia 119 (2017) 332.

[82] Y. Li, J. Luo, X. Hu, X. Wang, J. Liang, K. Yu, J. Alloys Compd. 651 (2015) 685.

[83] P. Roy, S. Berger, P. Schmuki, Angew. Chem. Int. Ed. 50 (2011) 2904.

[84] B. Sarkar, N. Singhal, R. Goyal, A. Bordoloi, L.S. 
Konathala, U. Kumar, R. Bal, Catal. Commun. 74 (2016) 43. [85] S. Shen, J. Chen, M. Wang, X. Sheng, X. Chen, X. Feng, S.S. Mao, Prog. Mater. Sci. 98 (2018) 299.

[86] J. Singh, S.A. Khan, J. Shah, R. Kotnala, S. Mohapatra, Appl. Surf. Sci. 422 (2017) 953.

[87] T. Tao, I.-T. Bae, K.B. Woodruff, K. Sauer, J. Cho, Ceram. Int. 45 (2019) 23216.

[88] C. Qizheng, D. Xiangting, W. Jinxian, L. Mei, J. Rare Earths 26 (2008) 664.

[89] R. Sabetrasekh, H. Tiainen, J. Reseland, J. Will, J. Ellingsen, S. Lyngstadaas, H. Haugen, Biomed. Mater. 5 (2010) 15003.

[90] H. Xu, Q. Zhang, C. Zheng, W. Yan, W. Chu, Appl. Surf. Sci. 257 (2011) 8478.

[91] E. Beltrán-Partida, A. Moreno-Ulloa, B. Valdez-Salas, C. Velasquillo, M. Carrillo, A. Escamilla, E. Valdez, F. Villarreal, Materials 8 (2015) 867.

[92] S. Chen, Y. Guo, R. Liu, S. Wu, J. Fang, B. Huang, Z. Li, Z. Chen, Z. Chen, Colloids Surf. B 164 (2018) 58.

[93] A. Hajjaji, M. Elabidi, K. Trabelsi, A. Assadi, B. Bessais, S. Rtimi, Colloids Surf. B 170 (2018) 92.

[94] M.-H. Kim, K. Park, K.-H. Choi, S.-H. Kim, S. Kim, C.-M. Jeong, J.-B. Huh, Int. J. Mol. Sci. 16 (2015) 10324.

[95] D. Khang, J. Lu, C. Yao, K.M. Haberstroh, T.J. Webster, Biomaterials 29 (2008) 970.

[96] B.K. Mutuma, G.N. Shao, W.D. Kim, H.T. Kim, J. Colloid Interface Sci. 442 (2015) 1.

[97] N. Swami, Z. Cui, L.S. Nair, J. Heat Transfer 133 (2011) 34002.

[98] A. Tampieri, G. Celotti, E. Landi, M. Sandri, N. Roveri, G. Falini, J. Biomed. Mater. Res. A 67 (2003) 618.

[99] G. Wang, H. Feng, W. Jin, A. Gao, X. Peng, W. Li, H. Wu, Z. Li, P.K. Chu, Appl. Surf. Sci. 414 (2017) 230.

[100] S. Winardi, R.R. Mukti, K.-N.P. Kumar, J. Wang, W. Wunderlich, T. Okubo, Langmuir 26 (2010) 4567.

[101] N.K. Awad, S.L. Edwards, Y.S. Morsi, Mater. Sci. Eng. C 76 (2017) 1401.

[102] L.M. Bjursten, L. Rasmusson, S. Oh, G.C. Smith, K.S. Brammer, S. Jin, J. Biomed. Mater. Res. A 92 (2010) 1218. [103] S.M.G. El-Rab, S.A. Fadl-Allah, A. Montser, Appl. Surf. Sci. 261 (2012) 1.

[104] A. Bandyopadhyay, A. Shivaram, I. Mitra, S. Bose, Acta Biomater. 96 (2019) 686.

[105] K. Cowden, M.F. Dias-Netipanyj, K.C. Popat, Nanomedicine 17 (2019) 380.

[106] F. Visentin, A. Galenda, M. Fabrizio, S. Battiston, N. Brianese, R. Gerbasi, V. Zin, N. El Habra, Appl. Surf. Sci. 490 (2019) 568.

[107] T. Wang, Z. Weng, X. Liu, K.W. Yeung, H. Pan, S. Wu, Bioact. Mater. 2 (2017) 44.

[108] M. Enayati-Jazi, M. Solati-Hashjin, A. Nemati, F. Bakhshi, Superlattices Microstruct. 51 (2012) 877.

[109] A.E. Hannora, S. Ataya, J. Alloys Compd. 658 (2016) 222.

[110] H.-W. Kim, Y.-H. Koh, L.-H. Li, S. Lee, H.-E. Kim, Biomaterials 25 (2004) 2533.

[111] P. Sharma, A. Trivedi, H. Begam, Mater. Today Proc.
16 (2019) 302.

[112] S. Pushpakanth, B. Srinivasan, B. Sreedhar, T. Sastry, Mater. Chem. Phys. 107 (2008) 492.

[113] S.F. Robertson, A. Bandyopadhyay, S. Bose, Surf. Coat. Technol. 372 (2019) 140.

[114] D. Sidane, D. Chicot, S. Yala, S. Ziani, H. Khireddine, A. Iost, X. Decoopman, Thin Solid Films 593 (2015) 71.

[115] F. Visentin, N. El Habra, M. Fabrizio, N. Brianese, R. Gerbasi, L. Nodari, V. Zin, A. Galenda, Surf. Coat. Technol. 378 (2019) 125049.

[116] H. Zhou, J.G. Lawrence, S.B. Bhaduri, Acta Biomater. 8 (2012) 1999.

[117] N.K. Allam, C.A. Grimes, Langmuir 25 (2009) 7234.

[118] M. Imran, S. Riaz, S. Naseem, Mater. Today Proc. 2 (2015) 5455.

[119] S. Mahshid, M. Askari, M.S. Ghamsari, N. Afshar, S. Lahuti, J. Alloys Compd. 478 (2009) 586.

[120] S. Kim, M. Kim, S.-H. Hwang, S.K. Lim, Appl. Catal. B 123 (2012) 391.

[121] C. Kuchi, G. Harish, P.S. Reddy, Ceram. Int. 44 (2018) 5266.

[122] M. Someswararao, R. Dubey, P. Subbarao, S. Singh, Results Phys. 11 (2018) 223.

[123] M. Vahtrus, A. Šutka, S. Vlassov, A. Šutka, B. Polyakov, R. Saar, L. Dorogin, R. Lohmus, Mater. Charact. 100 (2015) 98.

[124] G.J. Owens, R.K. Singh, F. Foroutan, M. Alqaysi, C.-M. Han, C. Mahapatra, H.-W. Kim, J.C. Knowles, Prog. Mater. Sci. 77 (2016) 1.

[125] X. Yan, X. Chen, in "Encyclopedia of inorganic and bioinorganic chemistry”, John Wiley Sons (2015) 1.

[126] W. Xu, W.Y. Hu, M.H. Li, Q.Q. Ma, P.D. Hodgson, C.E. Wen, Trans. Nonferrous Met. Soc. China 16 (2006) s209.

[127] M.F. Kunrath, R. Hubler, R.S. Shinkai, E.R. Teixeira, ChemistrySelect 3 (2018) 11180.

[128] S. Areva, V. Ääritalo, S. Tuusa, M. Jokinen, M. Lindén, T. Peltola, J. Mater. Sci. Mater. Med. 18 (2007) 1633.

[129] G. Crawford, N. Chawla, K. Das, S. Bose, A. Bandyopadhyay, Acta Biomater. 3 (2007) 359.

[130] M.A. Khan, U. Farva, Surf. Interfaces 6 (2017) 202.

[131] S. Sista, A. Nouri, Y. Li, C. Wen, P.D. Hodgson, G. Pande, J. Biomed. Mater. Res. A 101 (2013) 3416.

[132] W. Xu, W. Hu, M. Li, Q. Ma, P. Hodgson, C. Wen, Trans. Nonferrous Met. Soc. China 16 (2006) s209.

[133] H.P. Quiroz, C.P. Barrera-Patiño, R.R. Rey-González, A. Dussan, Photonics Nanostruct. 22 (2016) 46.

[134] M.A. Rasheed, K. Ahmad, N. Khaliq, Y. Khan, M. Aftab Rafiq, A. Waheed, A. Shah, A. Mahmood, G. Ali, Curr. Appl. Phys. 18 (2018) 297.

[135] X. Chen, S.S. Mao, Chem. Rev. 107 (2007) 2891.

[136] D. Kowalski, D. Kim, P. Schmuki, Nano Today 8 (2013) 235.

[137] D. Regonini, C.R. Bowen, A. Jaroenworaluck, R. Stevens, Mater. Sci. Eng. R Rep. 74 (2013) 377.

[138] Y. Wang, Y. He, Q. Lai, M. Fan, J. Environ. Sci. 26 (2014) 2139. 
[139] C.L. Wong, Y.N. Tan, A.R. Mohamed, J. Environ. Manage. 92 (2011) 1669.

[140] T. Tenkyong, J.S.S. Mary, B. Praveen, K. Pugazhendhi, D. Sharmila, J.M. Shyla, Mater. Sci. Semicond. Process. 83 (2018) 150.

[141] C.T. Teodorescu-Soare, C. Catrinescu, M. Dobromir, G. Stoian, A. Arvinte, D. Luca, J. Electroanal. Chem. 823 (2018) 388 .

[142] B.B. Çirak, S.M. Karadeniz, T. Kilinç, B. Caglar, A.E. Ekinci, H. Yelgin, M. Kürekçi, Ç. Çirak, Vacuum 144 (2017) 183.

[143] T. Hoseinzadeh, Z. Ghorannevis, M. Ghoranneviss, Appl. Phys. A 123 (2017) 436.

[144] F. Nasirpouri, I. Yousefi, E. Moslehifard, J. KhalilAllafi, Surf. Coat. Technol. 315 (2017) 163.

[145] S. Chen, Q. Chen, M. Gao, S. Yan, R. Jin, X. Zhu, Surf. Coat. Technol. 321 (2017) 257.

[146] E. Zalnezhad, E. Maleki, S. Banihashemian, J. Park, Y.B. Kim, M. Sarraf, A. Sarhan, S. Ramesh, Mater. Res. Bull. 78 (2016) 179.

[147] L. Qin, Q. Chen, R. Lan, R. Jiang, X. Quan, B. Xu, F. Zhang, Y. Jia, J. Mater. Sci. Technol. 31 (2015) 1059.

[148] Z. Lockman, S. Sreekantan, S. Ismail, L. SchmidtMende, J.L. MacManus-Driscoll, J. Alloys Compd. 503 (2010) 359 .

[149] W. Yu, Y. Zhang, X. Jiang, F. Zhang, Oral Dis. 16 (2010) 624

[150] Z. Liu, X. Zhang, S. Nishimoto, T. Murakami, A. Fujishima, Environ. Sci. Technol. 42 (2008) 8547.

[151] H.E. Prakasam, K. Shankar, M. Paulose, O.K. Varghese, C.A. Grimes, J. Phys. Chem. C 111 (2007) 7235.

[152] S. Bauer, S. Kleber, P. Schmuki, Electrochem. Commun. 8 (2006) 1321.

[153] Q. Cai, M. Paulose, O.K. Varghese, C.A. Grimes, J. Mater. Res. 20 (2005) 230.

[154] A. Ghicov, H. Tsuchiya, J.M. Macak, P. Schmuki, Electrochem. Commun. 7 (2005) 505.

[155] M. Andrade-Guel, L. Díaz-Jiménez, D. CortésHernández, C. Cabello-Alvarado, C. Ávila-Orta, P. BartoloPérez, P. Gamero-Melo, Bol. Soc. Esp. Ceram. V. 58 (2019) 171.

[156] J. Liang, J. Wang, K. Song, X. Wang, K. Yu, C. Liang, J. Rare Earths 37 (2019) 1.

[157] V. Singh, A. Rao, A. Tiwari, P. Yashwanth, M. Lal, U. Dubey, S. Aich, B. Roy, J. Phys. Chem. Solids 134 (2019) 262.

[158] E. Blanco, M. Domínguez, J. González-Leal, E. Márquez, J. Outón, M. Ramírez-del-Solar, Appl. Surf. Sci. 439 (2018) 736.

[159] R.G. Nair, S. Ojah, P.M. Kumar, S. Nikhil, S. Samdarshi, Mater. Lett. 221 (2018) 313.

[160] T.N. Singh, T.G. Devi, S.D. Singh, Nano-Struct. Nano-Obj. 11 (2017) 65.

[161] T. Balaganapathi, B. Kaniamuthan, S. Vinoth, P. Thilakan, Mater. Chem. Phys. 189 (2017) 50.

[162] D. Dastan, Appl. Phys. A 123 (2017) 699.

[163] F. Dejene, M. Onani, P. Tarus, Physica B Condens.
Matter 480 (2016) 213.

[164] B. Tryba, M. Tygielska, C. Colbeau-Justin, E. KusiakNejman, J. Kapica-Kozar, R. Wróbel, G. Żołnierkiewicz, N. Guskos, Mater. Res. Bull. 84 (2016) 152.

[165] B. Liu, J. Xiao, L. Xu, Y. Yao, B.F. Costa, V.F. Domingos, E.S. Ribeiro, F.-N. Shi, K. Zhou, J. Su, Int. J. Hydrog. Energy 40 (2015) 4945.

[166] Z. Li, Y. Zhu, J. Wang, Q. Guo, J. Li, Ceram. Int. 41 (2015) 9057.

[167] A.K. Tripathi, M.C. Mathpal, P. Kumar, M.K. Singh, M. Soler, A. Agarwal, J. Alloys Compd. 622 (2015) 37.

[168] S. Berger, R. Hahn, P. Roy, P. Schmuki, Phys. Status Solidi B 247 (2010) 2424.

[169] G. Cao, Nanostructures and nanomaterials: synthesis, properties and applications, World Sci. (2004).

[170] L.L. Hench, J.M. Polak, Science 295 (2002) 1014.

[171] M. Navarro, A. Michiardi, O. Castano, J. Planell, J. R. Soc. Interface 5 (2008) 1137.

[172] Y. Xia, Nat. Mater. 7 (2008) 758.

[173] Z.-G. Zhang, Z.-H. Li, X.-Z. Mao, W.-C. Wang, Cytotechnology 63 (2011) 437.

[174] K.S. Brammer, S. Oh, C.J. Cobb, L.M. Bjursten, H. van der Heyde, S. Jin, Acta Biomater. 5 (2009) 3215.

[175] S.A. Catledge, M.D. Fries, Y.K. Vohra, W.R. Lacefield, J.E. Lemons, S. Woodard, R. Venugopalanc, J. Nanosci. Nanotechnol. 2 (2002) 293.

[176] S. Minagar, C.C. Berndt, J. Wang, E. Ivanova, C. Wen, Acta Biomater. 8 (2012) 2875.

[177] A.W. Tan, B. Pingguan-Murphy, R. Ahmad, S.A. Akbar, J. Mater. Sci. 48 (2013) 8337.

[178] B. Zhang, D. Myers, G. Wallace, M. Brandt, P. Choong, Int. J. Mol. Sci. 15 (2014) 11878.

[179] S. Bauer, P. Schmuki, K. Von Der Mark, J. Park, Prog. Mater. Sci. 58 (2013) 261.

[180] R. Junker, A. Dimakis, M. Thoneick, J.A. Jansen, Clin. Oral Implants Res. 20 (2009) 185.

[181] H. Liu, T.J. Webster, Biomaterials 28 (2007) 354.

[182] L.E. McNamara, R.J. McMurray, M.J. Biggs, F. Kantawong, R.O. Oreffo, M.J. Dalby, J. Tissue Eng. 1 (2010) 120623.

[183] A. Wennerberg, T. Albrektsson, B. Andersson, J. Krol, Clin. Oral Implants Res. 6 (1995) 24.

[184] A. Wennerberg, C. Hallgren, C. Johansson, S. Danelli, Clin. Oral Implants Res. 9 (1998) 11.

[185] M. Fathi, B. Akbari, A. Taheriazam, Mater. Sci. Eng. C 103 (2019) 109743.

[186] M.F. Dias-Netipanyj, K. Cowden, L.S. Santos, S.C. Cogo, S. Elifio-Esposito, K.C. Popat, P. Soares, Mater. Sci. Eng. C 103 (2019) 109850.

[187] Y. Li, Y. You, B. Li, Y. Song, A. Ma, B. Chen, W. Han, C. Li, J. Hard Tissue Biol. 28 (2019) 13.

[188] W.-E. Yang, H.-H. Huang, Appl. Surf. Sci. 471 (2019) 1041.

[189] P. Agilan, N. Rajendran, Appl. Surf. Sci. 439 (2018) 66.

[190] D.P. Bhattarai, S. Shrestha, B.K. Shrestha, C.H. Park, C.S. Kim, Chem. Eng. J. 350 (2018) 57. 
[191] R. Aguirre, M. Echeverry Rendón, D. Quintero, J.G. Castaño, M.C. Harmsen, S. Robledo, F. Echeverría E., J. Biomed. Mater. Res. A 106 (2018) 1341.

[192] N. Khoshnood, A. Zamanian, A. Massoudi, Mater. Lett. 185 (2016) 374.

[193] Y. Bai, I.S. Park, H.H. Park, M.H. Lee, T.S. Bae, W. Duncan, M. Swain, Surf. Interface Anal. 43 (2011) 998.

[194] J. Park, S. Bauer, K.A. Schlegel, F.W. Neukam, K. von der Mark, P. Schmuki, Small 5 (2009) 666.

[195] K. Das, S. Bose, A. Bandyopadhyay, J. Biomed. Mater. Res. A 90 (2009) 225.

[196] J. Kunze, L. Müller, J.M. Macak, P. Greil, P. Schmuki, F.A. Müller, Electrochim. Acta 53 (2008) 6995.

[197] K.C. Popat, L. Leoni, C.A. Grimes, T.A. Desai, Biomaterials 28 (2007) 3188.

[198] S. Oh, C. Daraio, L.H. Chen, T.R. Pisanic, R.R. Finones, S. Jin, J. Biomed. Mater. Res. A 78 (2006) 97.

[199] B. Burnat, J. Robak, A. Leniart, I. Piwoński, D. Batory, Ceram. Int. 43 (2017) 13735.

[200] B. Burnat, J. Robak, D. Batory, A. Leniart, I. Piwoński, S. Skrzypek, M. Brycht, Surf. Coat. Technol. 280 (2015) 291.

[201] J. Coreño, A. Martínez, O. Coreño, A. Bolarín, F. Sánchez, J. Biomed. Mater. Res. A 64 (2003) 131.

[202] M. Uchida, H.M. Kim, T. Kokubo, S. Fujibayashi, T. Nakamura, J. Biomed. Mater. Res. A 64 (2003) 164.

[203] T. Peltola, M. Jokinen, H. Rahiala, M. Pätsi, J. Heikkilä, I. Kangasniemi, A. Yli-Urpo, J. Biomed. Mater. Res. 51 (2000) 200.

[204] E. Beltrán-Partida, B. Valdéz-Salas, A. Moreno-Ulloa, A. Escamilla, M.A. Curiel, R. Rosales-Ibáñez, F. Villarreal, D.M. Bastidas, J.M. Bastidas, J. Nanobiotechnology 15 (2017) 10.

[205] A.L. Escada, R.Z. Nakazato, A.P.R.A. Claro, Mater. Res. 20 (2017) 1282.

[206] K. Indira, U.K. Mudali, T. Nishimura, N. Rajendran, J. Bio Tribo-Corros. 1 (2015) 28.

[207] L. Liu, T.J. Webster, in "Orthopedic biomaterials", B. Liu, T. Webster (Eds.), Springer (2017) 31.

[208] A. Rafieerad, E. Zalnezhad, A. Bushroa, A. Hamouda, M. Sarraf, B. Nasiri-Tabrizi, Surf. Coat. Technol. 265 (2015) 24.

[209] Y. Fu, A. Mo, Nanoscale Res. Lett. 13 (2018) 187. [210] K.S. Brammer, S. Oh, C.J. Cobb, L.M. Bjursten, H. van der Heyde, S. Jin, Acta Biomater. 5 (2009) 3215.

[211] K.S. Brammer, C.J. Frandsen, S. Jin, Trends Biotechnol. 30 (2012) 315.

[212] B.S. Smith, S. Yoriya, T. Johnson, K.C. Popat, Acta Biomater. 7 (2011) 2686.

[213] C. Eriksson, H. Nygren, K. Ohlson, Biomaterials 25 (2004) 4759.

[214] R.A. Gittens, L. Scheideler, F. Rupp, S.L. Hyzy, J. Geis-Gerstorfer, Z. Schwartz, B.D. Boyan, Acta Biomater. 10 (2014) 2907.

[215] Z. Jia, P. Xiu, M. Li, X. Xu, Y. Shi, Y. Cheng, S. Wei,
Y. Zheng, T. Xi, H. Cai, Biomaterials 75 (2016) 203.

[216] S. Rani, S.C. Roy, M. Paulose, O.K. Varghese, G.K. Mor, S. Kim, S. Yoriya, T.J. LaTempa, C. Grimes, Phys. Chem. Chem. Phys. 12 (2010) 2780.

[217] U.F. Gunputh, H. Le, R.D. Handy, C. Tredwin, Mater. Sci. Eng. C 91 (2018) 638.

[218] H.J. Haugen, M. Monjo, M. Rubert, A. Verket, S.P. Lyngstadaas, J.E. Ellingsen, H.J. Rønold, J.C. Wohlfahrt, Acta Biomater. 9 (2013) 5390.

[219] R. Imani, M. Pazoki, D. Zupančič, M.E. Kreft, V. Kralj-Iglič, P. Veranič, A. Iglič, Protoplasma 253 (2016) 1439 .

[220] D. Loca, I. Narkevica, J. Ozolins, Mater. Lett. 159 (2015) 309.

[221] F.A. Akin, H. Zreiqat, S. Jordan, M.B. Wijesundara, L. Hanley, J. Biomed. Mater. Res. 57 (2001) 588.

[222] F. Utku, E. Seckin, G. Goller, C. Tamerler, M. Urgen, Appl. Surf. Sci. 350 (2015) 62.

[223] D.W. Hutmacher, J.T. Schantz, C.X.F. Lam, K.C. Tan, T.C. Lim, J. Tissue Eng. Regen. Med. 1 (2007) 245.

[224] A.C. Jones, C.H. Arns, D.W. Hutmacher, B.K. Milthorpe, A.P. Sheppard, M.A. Knackstedt, Biomaterials 30 (2009) 1440.

[225] V. Karageorgiou, D. Kaplan, Biomaterials 26 (2005) 5474 .

[226] T.S. Karande, J.L. Ong, C.M. Agrawal, Ann. Biomed. Eng. 32 (2004) 1728.

[227] H. Tiainen, D. Wiedmer, H.J. Haugen, J. Eur. Ceram. Soc. 33 (2013) 15.

[228] S. Bauer, J. Park, J. Faltenbacher, S. Berger, K. von der Mark, P. Schmuki, Integr. Biol. 1 (2009) 525.

[229] S. Bauer, J. Park, K. von der Mark, P. Schmuki, Acta Biomater. 4 (2008) 1576.

[230] A. Kar, K. Raja, M. Misra, Surf. Coat. Technol. 201 (2006) 3723.

[231] H. Tsuchiya, J.M. Macak, L. Müller, J. Kunze, F. Müller, P. Greil, S. Virtanen, P. Schmuki, J. Biomed. Mater. Res. A 77 (2006) 534.

[232] J. He, W. Zhou, X. Zhou, X. Zhong, X. Zhang, P. Wan, B. Zhu, W. Chen, J. Mater. Sci. Mater. Med. 19 (2008) 3465.

[233] H. Shi, R. Magaye, V. Castranova, J. Zhao, Part. Fibre Toxicol. 10 (2013) 15.

[234] R. Sawada, Y. Katou, H. Shibata, M. Katayama, T. Nonami, Int. J. Biomater. 2019 (2019) 7826373.

[235] B. Malhotra, M.A. Ali, Nanomaterials for biosensors: fundamentals and applications, Elsevier (2018) 183.

[236] V.D. Rani, L. Vinoth-Kumar, V. Anitha, K. Manzoor, M. Deepthy, V.N. Shantikumar, Acta Biomater. 8 (2012) 1976.

[237] C. von Wilmowsky, S. Bauer, R. Lutz, M. Meisel, F.W. Neukam, T. Toyoshima, P. Schmuki, E. Nkenke, K.A. Schlegel, J. Biomed. Mater. Res. B 89 (2009) 165.

[238] H. Zhang, Y. Sun, A. Tian, X.X. Xue, L. Wang, A. Alquhali, X. Bai, Int. J. Nanomedicine 8 (2013) 4379.

(Rec. 05/12/2019, Rev. 20/05/2020, 03/06/2020, Ac. 07/06/2020) 